\title{
Zmienność ilości i składu gazów pochodzących z degazacji rdzeni skalnych w profilu geologicznym otworu z obszaru LGOM
}

\section{Variability of the amount and composition of gases from the rock cores degassing in the geological profile of the borehole from the LGOM area}

\author{
Małgorzata Kania, Marek Janiga, Agnieszka Wciślak \\ Instytut Nafty i Gazu - Państwowy Instytut Badawczy
}

\begin{abstract}
STRESZCZENIE: Głównym celem badań było określenie zależności ilości i składu chemicznego gazów powstałych podczas procesu degazacji skał zróżnicowanych litologicznie i petrofizycznie w nawiązaniu do przykładowego profilu geologicznego otworu. Dla formacji miedzionośnych określenie tego typu prawidłowości dla różnych typów skał pozwoli na przewidywanie miejsc i kierunków ekshalacji gazowych, a w przyszłości może przyczynić się do utrzymania bezpieczeństwa w kopalniach. Przedmiotem badań były próbki skał pochodzące z wybranego pionowego otworu w obrębie formacji miedzionośnej z rejonu południowej części monokliny przedsudeckiej. Pobrane do badań próbki reprezentowały następujące serie litologiczne: piaskowiec czerwony i szary, dolomit, anhydryt oraz sól kamienną. W celu oceny gazonośności skał o różnym wykształceniu litofacjalnym przebadano skład molekularny oraz ilości wydzielonych gazów desorbowanych i resztkowych w obrębie wybranego otworu pionowego. Dodatkowo wszystkie próbki rdzeniowe poddano badaniom porozymetrycznym oraz przepuszczalności w celu oceny podstawowych parametrów petrofizycznych. Na podstawie uzyskanych wyników można stwierdzić, że ilość wydzielonego gazu resztkowego w całym obrębie profilu otworu doskonale koreluje z właściwościami petrofizycznymi, a dokładniej z wartościami porowatości całkowitej. Próbki pochodzące z serii piaskowcowej (zarówno czerwonego, jak i szarego piaskowca) charakteryzują się najwyższą porowatością całkowitą, sięgającą niemal $25 \%$, i w tych porach zostały skumulowane i zamknięte największe ilości gazu resztkowego. Nieco mniejsze ilości gazu wydzieliły się podczas degazacji próbki dolomitu wapnistego pobranej z głębokości 10,00 m, o stosunkowo wysokiej porowatości całkowitej rzędu 7,3\%, a jeszcze mniejsze z głębokości 8,35 m. Z kolei ilości gazu resztkowego dla soli kamiennej (Na1) oraz dla próbek anhydrytu (A1d) utrzymywały się na zdecydowanie niższym poziomie. Duże ilości gazu wydzielone z przestrzeni porowej rdzeni w trakcie procesu degazacji związane są z wysoką zawartością azotu nadmiarowego. Największe jego ilości wydzieliły się z serii piaskowców oraz z próbki dolomitu pobranej z głębokości 10,00 m, a więc z rdzeni o dużej porowatości całkowitej. Z kolei anomalnie wysokie wartości azotu nadmiarowego w gazie desorbowanym stwierdzono w próbce anhydrytu z głębokości 52,00 m (o stosunkowo niskiej porowatości). Obecność azotu nadmiarowego w tej próbce można thumaczyć selektywną adsorpcją gazu podczas migracji na duże odległości, a także możliwością powstawania lokalnych pułapek gazu.
\end{abstract}

Słowa kluczowe: gaz desorbowany, gaz resztkowy, skład molekularny, właściwości petrofizyczne, profil geologiczny, LGOM.

ABSTRACT: The main objective of the research was to determine the amount and chemical composition dependence of gases formed during the degassing process of lithologically and petrophysically varied rocks in reference to the geological profile of the borehole. In the case of copper-bearing formations, determining this type of regularity for different types of rocks will make it possible to predict places and directions of gas exhalation. This may contribute, in the future, to maintaining safety in mines. The subject of the research were rock samples from a selected vertical borehole within copper-bearing formation from the southern part of the Fore-Sudetic Monocline. The samples collected for testing represented the following lithological series: red and grey sandstone, dolomite, anhydrite and rock salt. In order to assess the gas-bearing capacity of rocks with different lithofacial structure, the molecular composition and the amount of desorbed and residual gases were tested within selected vertical well. In addition, all core samples were subjected to porosimetric and permeability tests to evaluate the basic petrophysical parameters. Based on the obtained results, it was found that the amount of evaporated residual gas in the whole area of the borehole profile correlates perfectly with petrophysical properties, and more specifically with the values of total porosity. Samples from the sandstone series (both red and grey sandstone) are characterized by the highest total porosity reaching almost $25 \%$ and in these rock pores, the largest amounts of residual gas were accumulated and closed. Slightly smaller amounts of gas were separated during the degassing process from the limestone dolomite sample, taken from the depth of $10.00 \mathrm{~m}$ with a relatively high total porosity of $7.3 \%$, and even smaller from the depth of $8.35 \mathrm{~m}$. The amount of residual gas for rock salt (Na1) and for anhydrite samples (A1d) remained significantly lower. Large amounts of gas separated from the pore

Autor do korespondencji: Małgorzata Kania, e-mail: kaniam@inig.pl

Artykuł nadesłano do Redakcji: 1.08.2019 r. Zatwierdzono do druku : 19.12.2019 r. 
space of cores during the degassing process are associated with a high content of excess nitrogen. The largest amounts were separated from a series of sandstones and from a sample of dolomite, taken from a depth of $10.00 \mathrm{~m}$, i.e. from cores with high total porosity. Additionally, anomalously high values of excess nitrogen in desorbed gas were found in the anhydrite sample, taken from a depth of $52.00 \mathrm{~m}$ (with relatively low porosity). The presence of excess nitrogen in this sample can be explained by selective gas adsorption during long-distance migration, as well as the possibility of forming of local gas traps.

Key words: desorbed gas, residual gas, molecular composition, petrophysical properties, geological profile, Legnica-Głogów Copper District (LGOM).

\section{Wstęp}

Obszar omawianych złóż rud miedzi, z którego zostały pobrane próbki do badań, stanowi południowo-zachodnią część monokliny przedsudeckiej. Monoklina przedsudecka od południowego zachodu graniczy z blokiem przedsudeckim, od północnego wschodu z synklinorium szczecińsko-łódzkim, na zachodzie jest połączona z perykliną Żar, a na wschodzie łączy się z monokliną śląsko-krakowską (Zawisza et al., 2010).

W budowie geologicznej monokliny przedsudeckiej można wyróżnić trzy piętra strukturalne. Pierwsze, stanowiące podłoże monokliny, to proterozoiczne skały krystaliczne i karbońskie skały osadowe. Na nich zalegają monoklinalnie ułożone osady permu i triasu, a w południowo-wschodniej części monokliny (rejon opolski) na permie i triasie lub na młodszych od triasu utworach mezozoicznych występują osady górnej kredy. Trzecie piętro stanowią utwory paleogenu i neogenu (Deczkowski et al., 1995; Kłapciński i Peryt, 2007).

Warunki tektoniczno-facjalne mają duże znaczenie dla migracji i akumulacji gazów. Obecność uskoków jest czynnikiem sprzyjającym pionowej (wertykalnej) migracji gazów z osadów karbonu poprzez czerwony spągowiec, w tym węglowodorów w silnie zaangażowanej tektonicznie południowej części złóż Legnicko-Głogowskiego Okręgu Miedziowego (LGOM). Z drugiej strony specyficzne warunki facjalno-tektoniczne mogą sprzyjać akumulacji węglowodorów i tworzeniu lokalnych ich nagromadzeń (Kondratowicz, 1998; Downorowicz, 2007), a także lateralnej migracji gazów wzdłuż stref tektonicznych i towarzyszących im spękań górotworu (Zawisza et al., 2010).

Głównym celem badań było określenie zależności ilości i składu chemicznego gazów powstałych podczas procesu degazacji skał zróżnicowanych litologicznie i petrofizycznie w nawiązaniu do konkretnego profilu geologicznego otworu.

\section{Metodyka badań}

\section{Degazacja rdzeni skalnych i analiza sktadu molekularnego gazu}

Próbki rdzeni skalnych zostały pobrane $\mathrm{z}$ wybranego otworu z rejonu Sieroszowic, a następnie jeszcze w kopalni umieszczone w szczelnych kanistrach desorpcyjnych na co najmniej 7 dni. Próbki mające służyć do oceny gazu desorbowanego (część gazu znajdująca się w otwartej przestrzeni porowej, która może swobodnie migrować) pobierano z pojemnika desorpcyjnego poprzez septę i poddawano analizom chromatograficznym. Po wykonaniu tych analiz na podstawie objętości pojemnika, wagi rdzenia oraz gęstości skały obliczono objętość przestrzeni wolnej w pojemniku. Następnie fragment rdzenia o masie około $20 \mathrm{~g}$ wraz ze stalową kulką zamknięto w cylindrze degazacyjnym i umieszczono w młynku kulowym, gdzie w ciągu 15 minut próbka została rozdrobniona. W kolejnym etapie poprzez septę pobrano wydzielony gaz resztkowy (część gazu, która jest zamknięta w przestrzeni porowej i jest uwalniana ze skały w trakcie procesu degazacji rdzeni) (Diamond i Schatzel, 1998), a następnie poddano go analizom chromatograficznym. Po uwzględnieniu wielkości i gęstości próbki skalnej oraz objętości pojemnika degazacyjnego przeliczono każdy ze składników gazu (Janiga i Kania, 2014) w odniesieniu do $1 \mathrm{~kg}$ próbki ( $\mu 1 / \mathrm{kg}$ skały).

Skład molekularny gazu desorbowanego i resztkowego oznaczony został przy użyciu dwukanałowego, zaworowego chromatografu gazowego Agilent 7890A poprzez określenie zawartości następujących składników: $\mathrm{O}_{2}, \mathrm{~N}_{2}, \mathrm{CO}_{2}, \mathrm{CO}, \mathrm{C}_{1}, \mathrm{C}_{2}, \mathrm{C}_{3}, \mathrm{i}-\mathrm{C}_{4}$, n- $\mathrm{C}_{4}$, neo- $\mathrm{C}_{5}, \mathrm{i}-\mathrm{C}_{5}, \mathrm{n}-\mathrm{C}_{5}$ oraz sum węglowodorów $\mathrm{C}_{6}, \mathrm{C}_{7}, \mathrm{C}_{8}, \mathrm{C}_{9}$ $\mathrm{i}_{10}$ (Kania i Janiga, 2011). W równoległej analizie określono stężenie $\mathrm{H}_{2} \mathrm{i}$ He oraz $\mathrm{H}_{2} \mathrm{~S}$ i innych związków siarki, takich jak merkaptan metylowy, merkaptan etylowy, siarczek dimetylowy, merkaptan i-propylowy, merkaptan n-propylowy, merkaptan i-butylowy, merkaptan n-butylowy (Kania i Janiga, 2018, 2019).

\section{Badania właściwości petrofizycznych}

Badanie wraz z parametryzacją przestrzeni porowej zostało wykonane z zastosowaniem porozymetrii rtęciowej przez pomiar krzywych ciśnień kapilarnych. Do tego typu badań wykorzystano porozymetr AutoPore IV 9500 firmy Micromeritics, stosując ciśnienia maksymalne 30 tys. psi. Pomiary gęstości wykonane natomiast zostały przy użyciu piknometru helowego AccuPyc II 1340 firmy Micromeritics. Zarówno pomiary gęstości, jak i porowatości zostały przeprowadzone dokładnie na tej samej próbce. Gęstość szkieletowa uzyskana 
z piknometru helowego została wykorzystana do korekty porowatości otwartej, otrzymanej z pomiaru porozymetrycznego. Natomiast oznaczenie współczynnika przepuszczalności efektywnej zostało wykonane przy użyciu azotu. Pomiar ten polegał na doprowadzeniu do ustalonego, laminarnego przepływu gazu roboczego przez próbkę badaną, a następnie za pomocą równania Darcy’ego wyliczeniu współczynnika przepuszczalności dla tzw. geometrii liniowej (Kania i Janiga, 2019).

\section{Charakterystyka próbek}

Przedmiotem badań były próbki skał w obrębie formacji miedzionośnej z rejonu Sieroszowic pochodzące z dwóch otworów, prowadzonych pionowo z jednego miejsca wyrobiska (o kącie nachylenia $+90^{\circ}$ od stropu i o kącie nachylenia $-90^{\circ}$ od spągu wyrobiska). Sumaryczna długość obydwu otworów (nazywanych dalej ,wybranym otworem pionowym”) wynosi $99 \mathrm{~m}$. Pobrane do badań próbki charakteryzowały się dużym zróżnicowaniem litologicznym, reprezentując m.in. piaskowiec czerwony i szary, dolomit wapnisty, anhydryt oraz sól kamienną. Dla ich rozróżnienia w nawiasach okrągłych podano głębokości od wyrobiska kopalnianego, z których zostały pobrane konkretne próbki do badań. Wartości dodatnie określają kierunek ich poboru od stropu, natomiast ujemne - od spągu wyrobiska.

W celu oceny gazonośności skał o różnym wykształceniu litofacjalnym przebadano skład molekularny oraz ilości wydzielonych gazów (zarówno desorbowanych, jak i resztkowych) w obrębie jednego, wybranego otworu pionowego. Wyniki badań chromatograficznych składu gazu desorbowanego zostały zebrane w tabeli 1, natomiast gazu resztkowego w tabeli 2. Dodatkowo wszystkie próbki rdzeniowe, tj. 3 próbki piaskowca (1 próbka piaskowca czerwonego i 2 próbki piaskowca szarego), 2 próbki dolomitu wapnistego, 6 próbek anhydrytu i 2 próbki soli kamiennej, poddano badaniom porozymetrycznym oraz przepuszczalności w celu oceny podstawowych parametrów petrofizycznych (tab. 3). Ze względu na zbyt małą ilość próbki rdzeniowej wycięcie walca o odpowiedniej średnicy i długości w kierunku poziomym, a tym samym wykonanie badań przepuszczalności poziomej (x) nie było możliwe.

\section{Związek pomiędzy profilem geologicznym otworu a ilością i składem gazów pochodzących z degazacji rdzeni skalnych}

Profil geologiczny badanego otworu obejmuje poszczególne serie skalne występujące w spągu i stropie poziomu miedzionośnego:
- P1 - piaskowce czerwonego spągowca;

- T1 - poziom łupku miedzionośnego;

- Ca1 - skały węglanowe wapienia cechsztyńskiego;

- Ald - anhydryt dolny;

- Na1 - najstarszą sól kamienną.

W każdej z tych serii skalnych mogą lokalnie gromadzić się gazy, stanowiąc odrębne strefy kumulacji (Zawisza et al., 2010).

Korelując wyniki badań chromatograficznych wydzielonych ilości gazów desorbowanych (tab. 1) oraz gazów resztkowych (tab. 2) z profilem geologicznym badanego otworu (rys. 1), łatwo zauważyć, że zdecydowanie najwyższa ilość gazu resztkowego uzyskana została z serii piaskowców (zarówno czerwonego, jak i szarego). Nieco mniejsze ilości gazu resztkowego wydzieliły się z kolei z próbki dolomitu wapnistego pobranej z głębokości 10,00 m, a jeszcze mniejsze $\mathrm{z}$ głębokości 8,35 m. Z kolei ilości gazu resztkowego dla soli kamiennej (Na1) oraz dla próbek anhydrytowych (A1d) utrzymywały się na zdecydowanie niższym poziomie, tj. w przedziale 86,8-1925,1 $\mu \mathrm{l} / \mathrm{kg}$ skały.

Ilości gazu resztkowego są skorelowane z właściwościami petrofizycznymi badanych skał (tab. 3), a dokładniej z wartościami porowatości całkowitej (rys. 3) i otwartej. Próbki pochodzące z serii piaskowcowej (zarówno czerwonego piaskowca, jak i szarego) charakteryzują się najwyższą porowatością całkowitą, sięgającą niemal 25\% (rys. 2). W tychże porach zostały również skumulowane i zamknięte największe ilości gazu resztkowego (w zakresie 204 695,8-327 262,6 $\mu 1 / \mathrm{kg}$ skały). Podobna sytuacja dotyczyła próbki dolomitu wapnistego pobranej z głębokości 10,00 m, w przypadku której stosunkowo wysoka porowatość całkowita rzędu 7,3\% skorelowana była z dużymi ilościami gazu wydzielonego w trakcie degazacji rdzenia - $119326,6 \mu \mathrm{l} / \mathrm{kg}$ skały.

Na podstawie uzyskanych wyników badań petrofizycznych na próbkach anhydrytowych można stwierdzić, że w analizowanym obszarze nie powinny występować warunki do złożowej koncentracji gazu ze względu na słabe właściwości kolektorskie skał (tj. bardzo niską przepuszczalność oraz małą porowatość). Jednak w przypadku próbki anhydrytowej pobranej z głębokości 52,00 m, o stosunkowo niskiej porowatości całkowitej rzędu 0,9\%, wydzieliła się największa ilość gazu desorbowanego (29 270,8 $\mu \mathrm{l} / \mathrm{kg}$ skały) spośród badanych litologii. W anhydrytach zatem mogą występować zamknięte ,pułapki gazowe” o stosunkowo niewielkich rozmiarach (Zawisza et al., 2010; Kania i Janiga, 2019) zawierające znaczne zawartości azotu nadmiarowego (rys. 4) i węglowodorów (rys. 5).

Duże ilości gazu wydzielone z przestrzeni porowej rdzeni w trakcie procesu degazacji (rys. 1) związane są z wysoką zawartością azotu nadmiarowego (rys. 4). Największe jego ilości wydzieliły się z serii piaskowców oraz z próbki dolomitu 


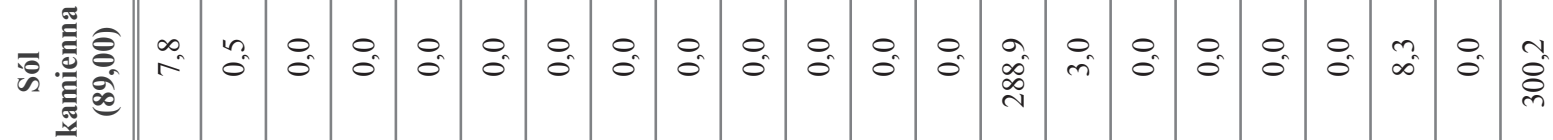

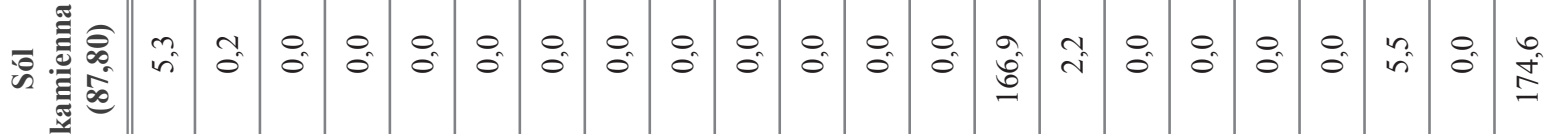

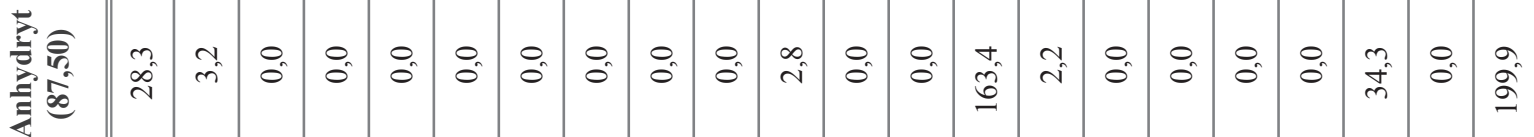

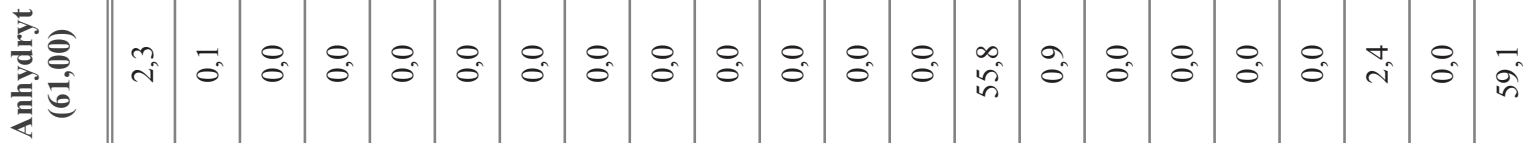

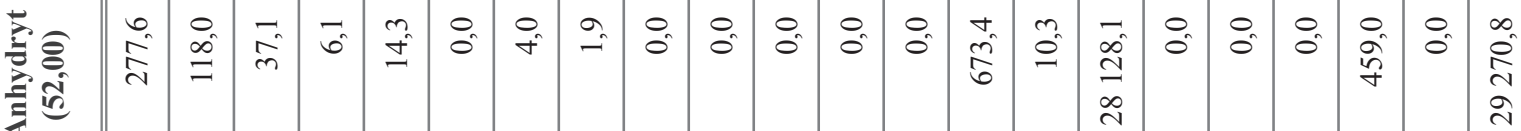
至荐 在焉

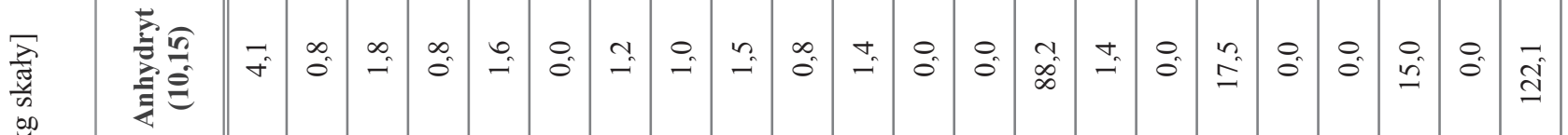

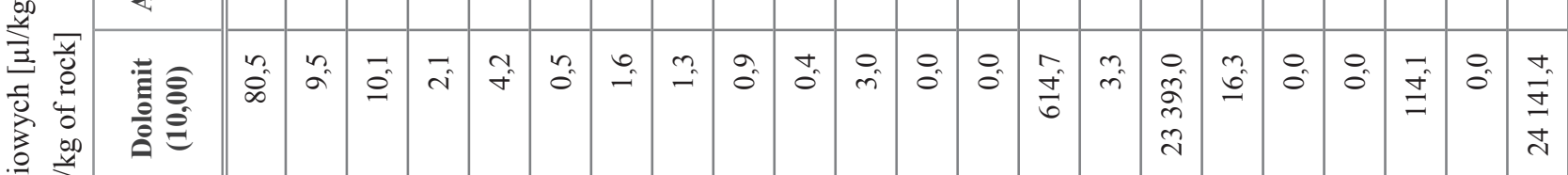
茛

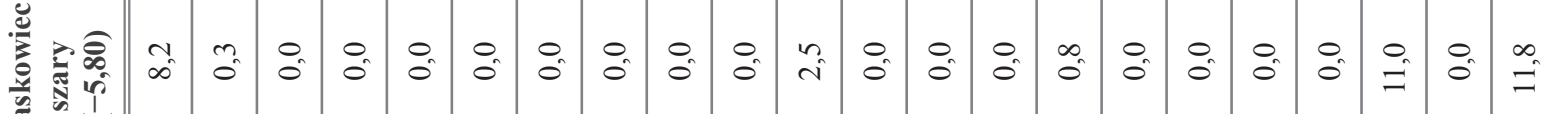
离 :

\section{递}

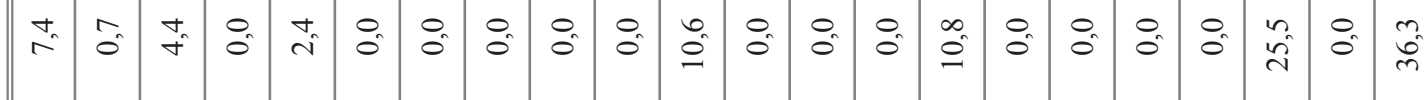
$\stackrel{\mathscr{2}}{3}$

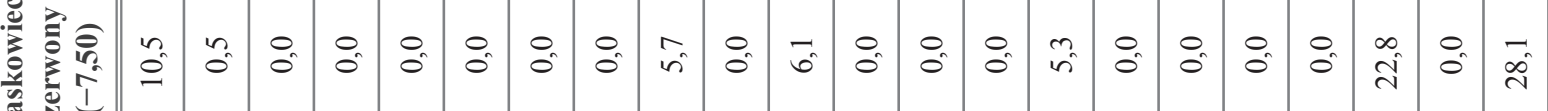
政 


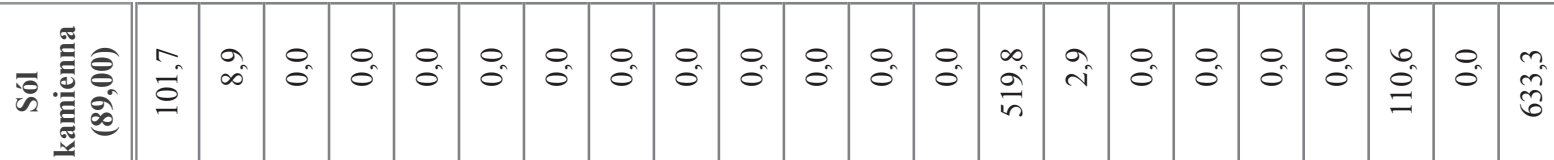

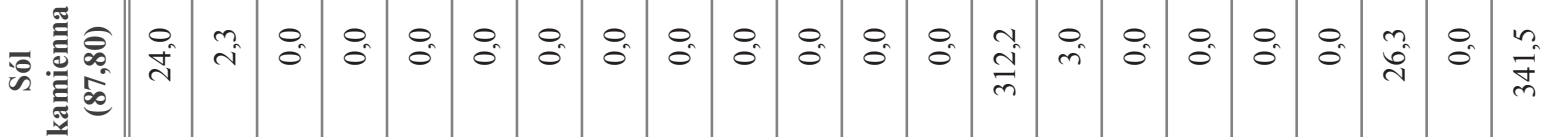

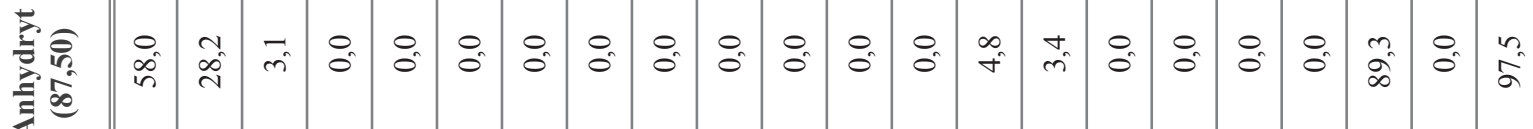

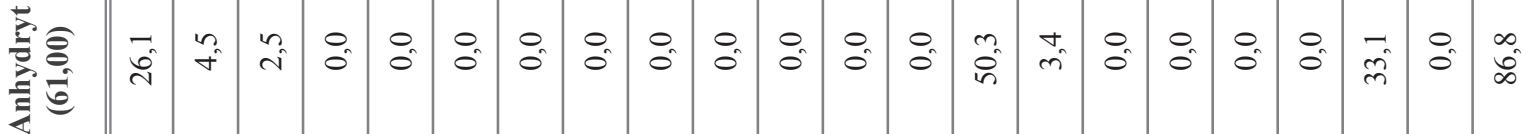

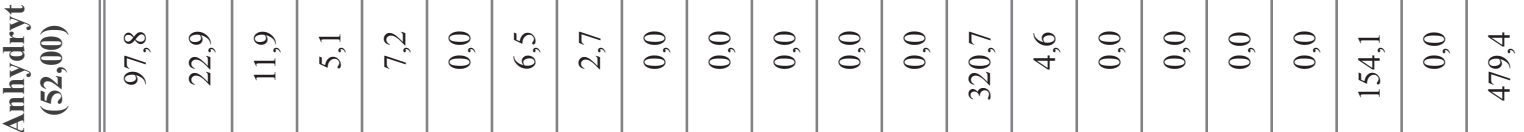

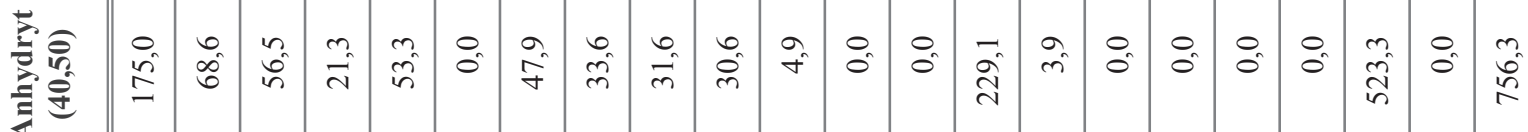

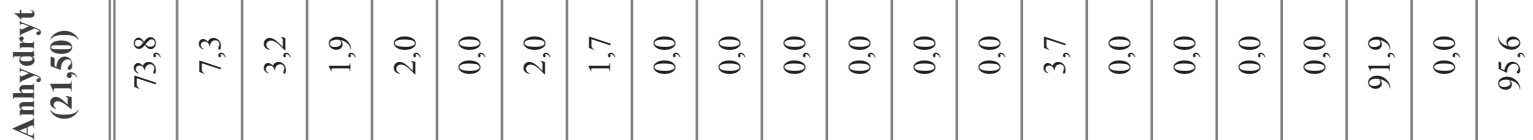

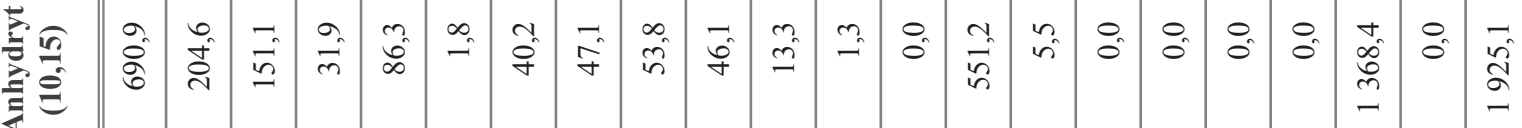

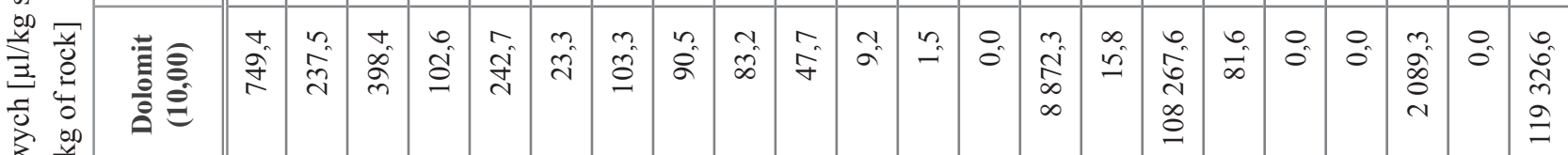

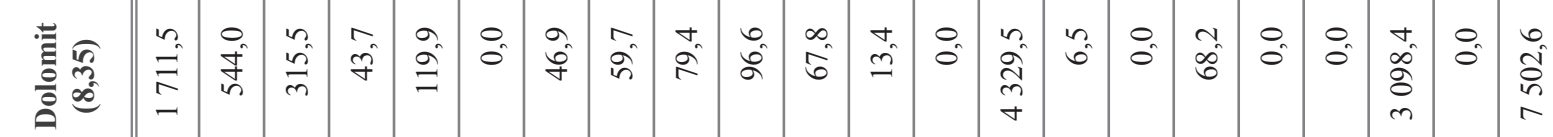

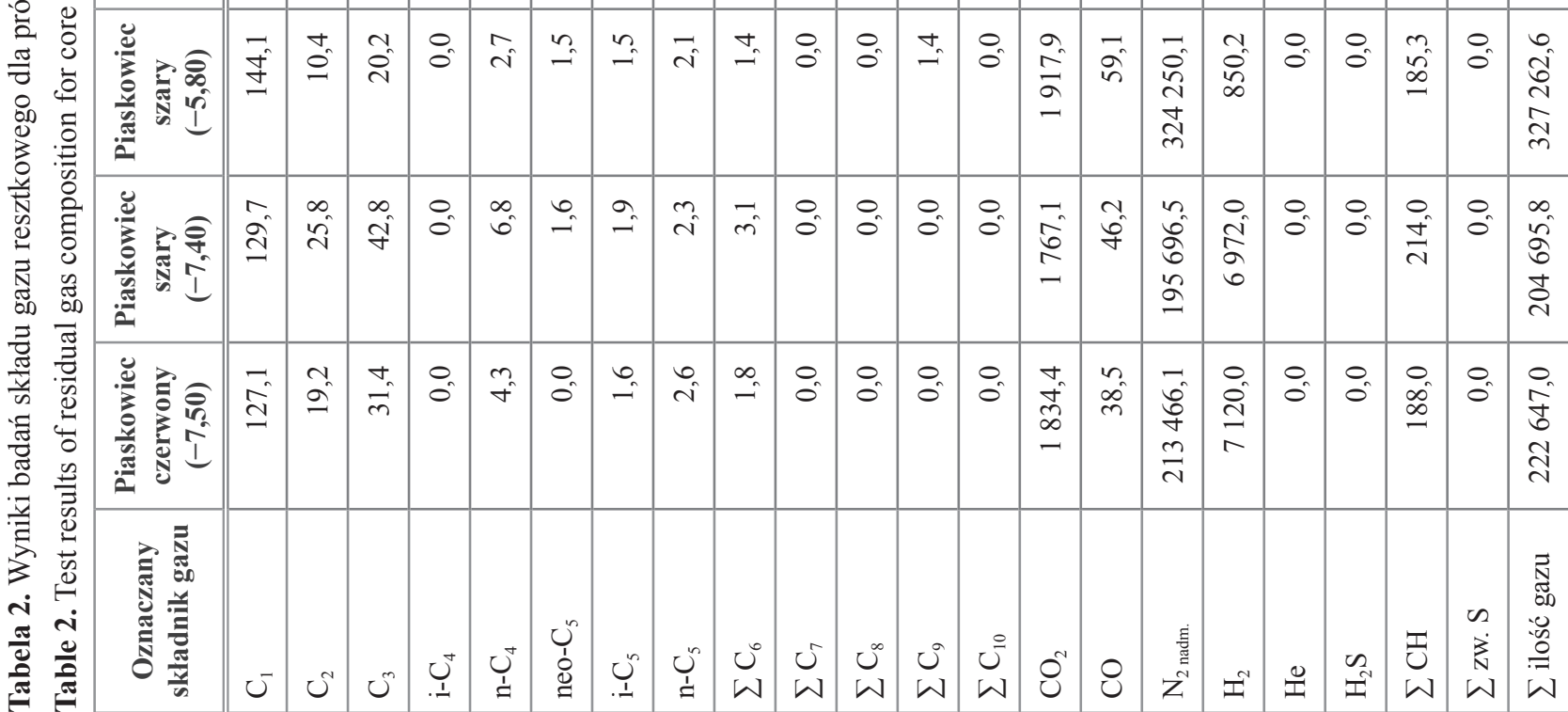




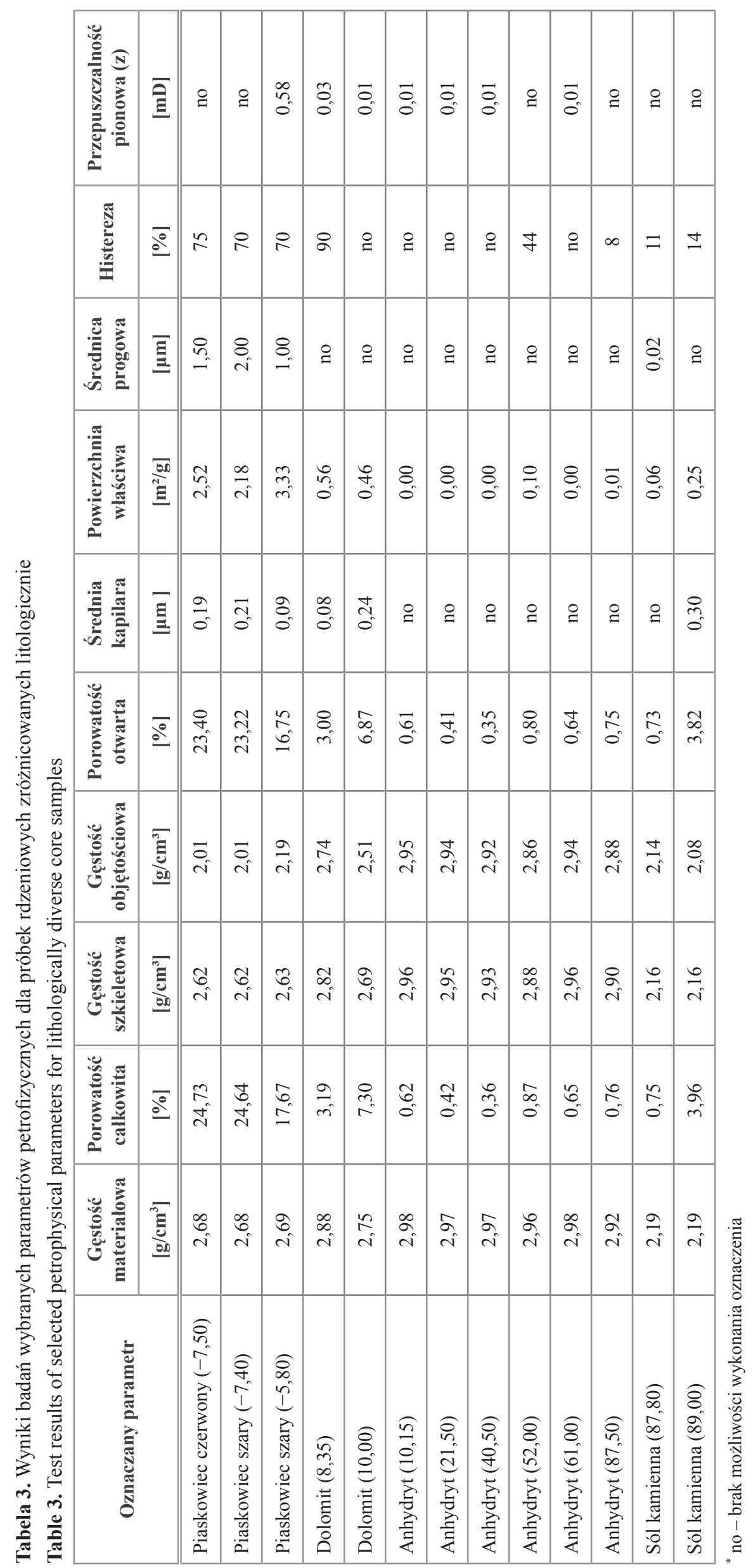




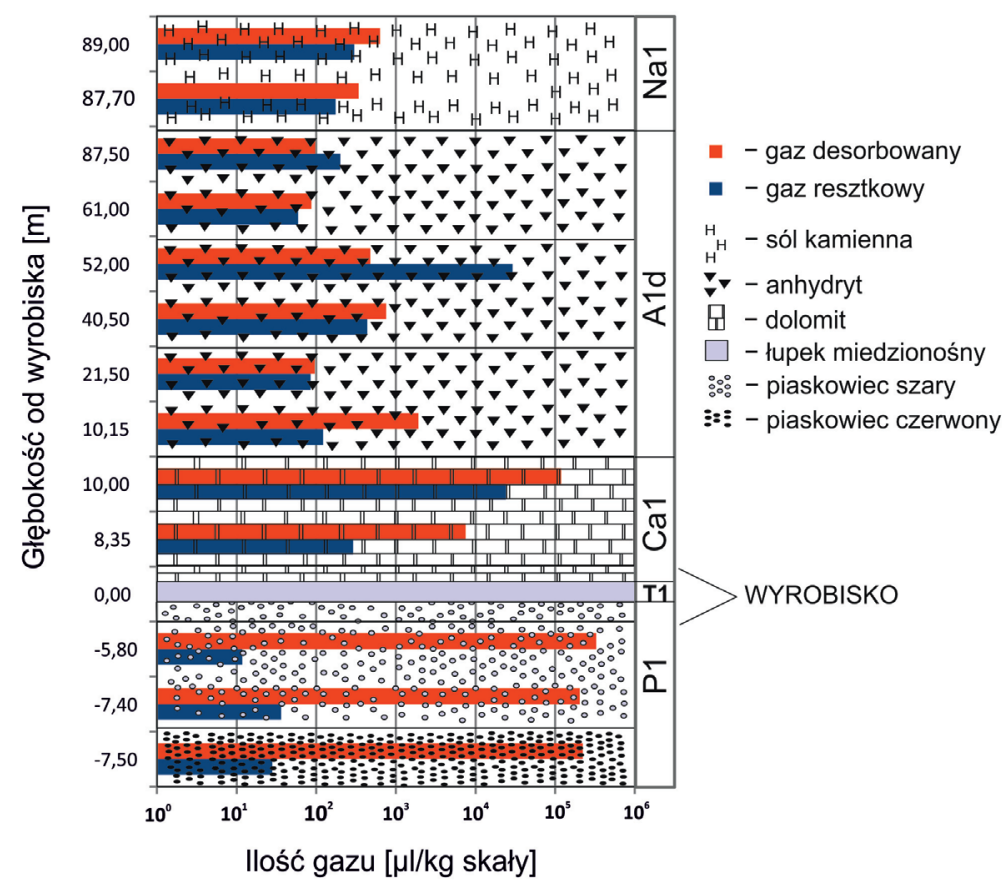

Rys. 1. Zmienność ilości gazu desorbowanego i resztkowego w profilu geologicznym otworu

Fig. 1. Variability of desorbed and residual gas amount in the geological profile of the borehole

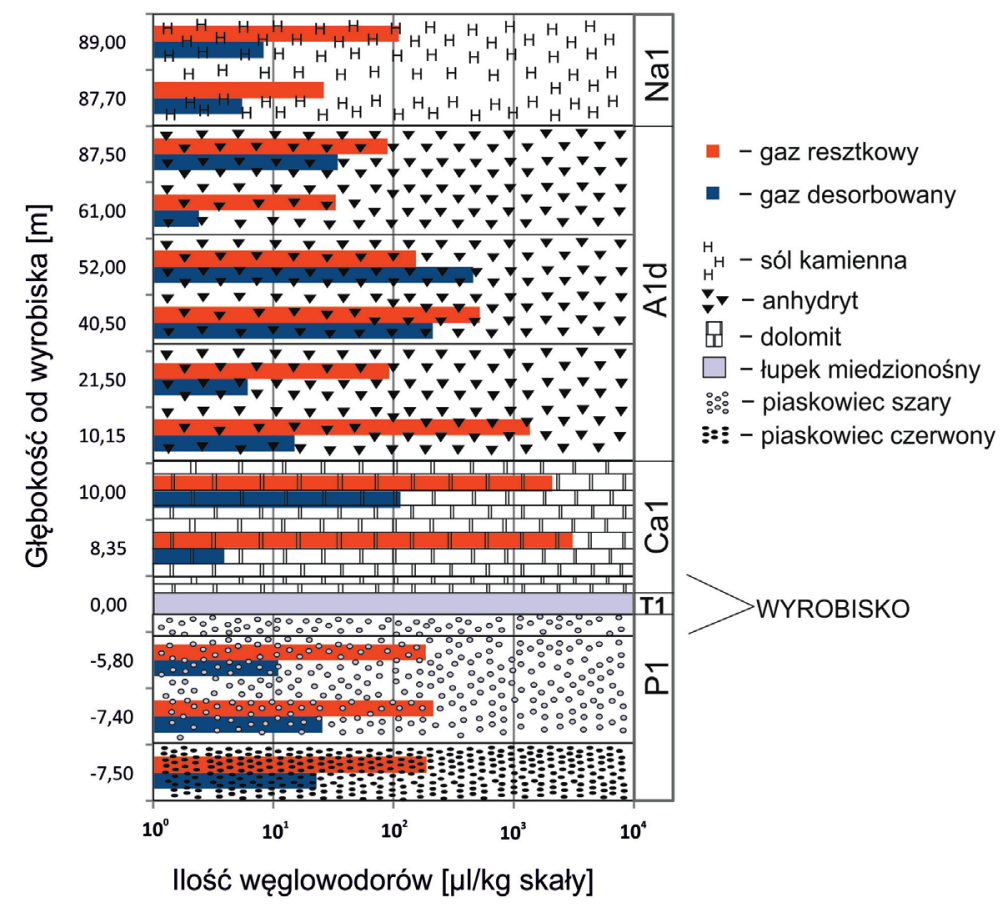

Rys. 2. Zmienność porowatości całkowitej dla rdzeni o różnym wykształceniu litologicznym

Fig. 2. Variability of the total porosity for cores with different lithological variation

pobranej z głębokości 10,00 m, a więc z rdzeni o dużej porowatości całkowitej. Z kolei anomalnie wysokie wartości azotu nadmiarowego $\mathrm{w}$ gazie desorbowanym stwierdzono w próbce anhydrytu z głębokości 52,00 m (o stosunkowo niskiej porowatości). Nadmiarowa ilość azotu w tej próbce może być związana z selektywną adsorpcją cząsteczek zachodzącą w trakcie migracji na duże odległości. Według licznych doniesień literaturowych (Kotarba et al., 2006; Poszytek et al., 2018) migracja gazu jest możliwa dzięki licznym szczelinom i pęknięciom z warstw karbońskich poprzez utwory czerwonego spągowca i skały węglanowe wapienia cechsztyńskiego. Aczkolwiek częściowo azot może mieć również związek z procesami abiogenicznymi zachodzącymi w płaszczu Ziemi (Kotarba et al., 2017).

Spośród badanych próbek reprezentujących poszczególne serie skalne to właśnie próbki dolomitów charakteryzowały się zdecydowanie najwyższymi ilościami węglowodorów w gazie resztkowym. Obecność gazu, który został zamknięty w licznych porach dolomitów (Suchan et al., 2013; Poszytek i Suchan, 2016; Poszytek et al., 2018), stanowi dość powszechne zjawisko (Kania i Janiga, 2018), stwarzając tym samym istotne zagrożenie dla wyrobisk górniczych (zwłaszcza w obrębie lokalnie mocniej mikroszczelinowatych, porowatych i przepuszczalnych dolomitów). Z kolei wyniki badań chromatograficznych na próbkach anhydrytowych i soli kamiennej sugerują, że w analizowanym obszarze (pomimo słabych właściwości kolektorskich skał) pojawiają się warunki sprzyjające tworzeniu się miejsc kumulacji gazowych z domieszką węglowodorów, tak jak w przypadku próbki soli kamiennej pobranej z głębokości 89,00 m, o porowatości całkowitej sięgającej niemal $4 \%$.

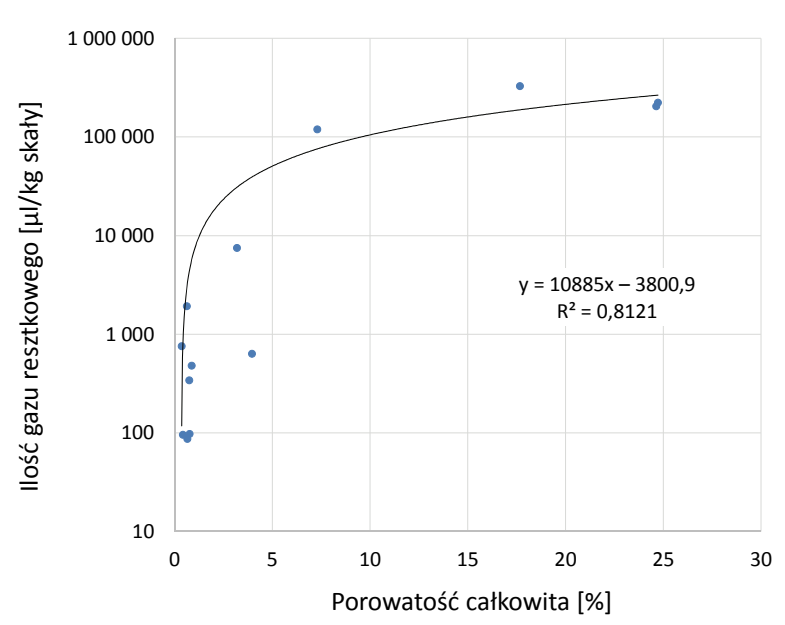

Rys. 3. Korelacja pomiędzy ilością gazu resztkowego a porowatością całkowitą badanych próbek rdzeniowych

Fig. 3. Correlation between the residual gas amount and total porosity of the tested core samples 


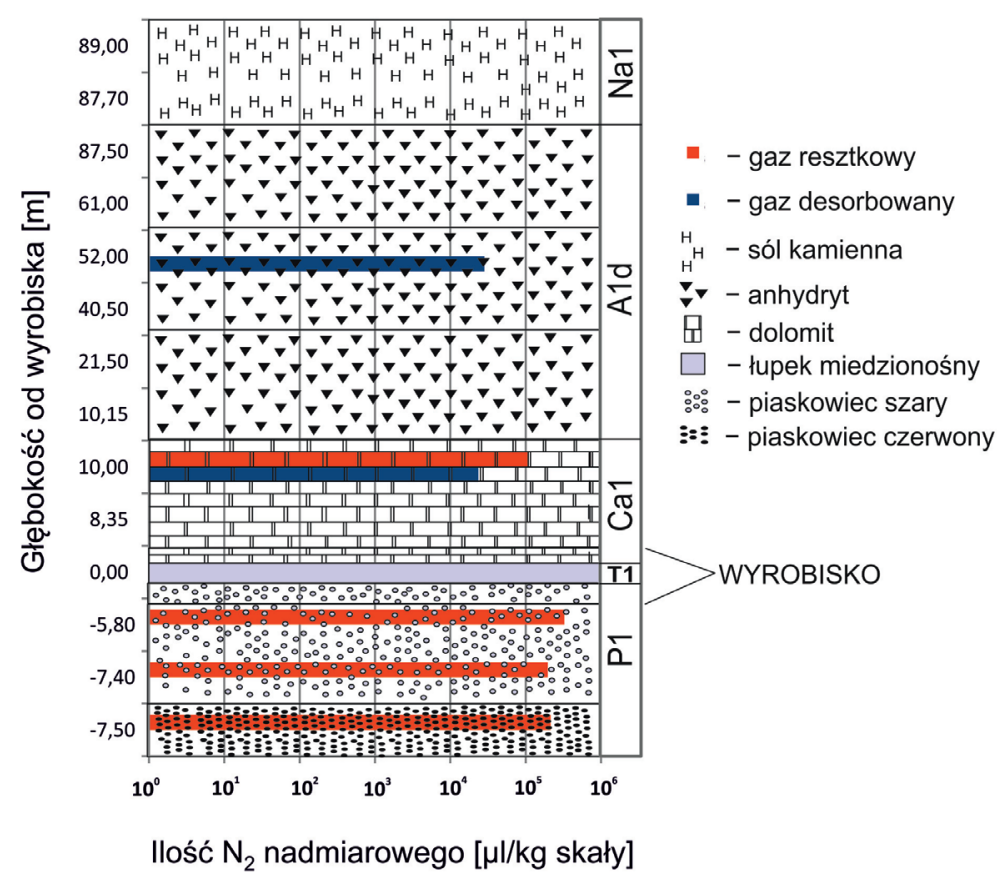

Rys. 4. Zmienność ilości azotu nadmiarowego w gazie desorbowanym i resztkowym w profilu geologicznym otworu

Fig. 4. Variability of the excess nitrogen amount in desorbed and residual gas in the geological profile of the borehole

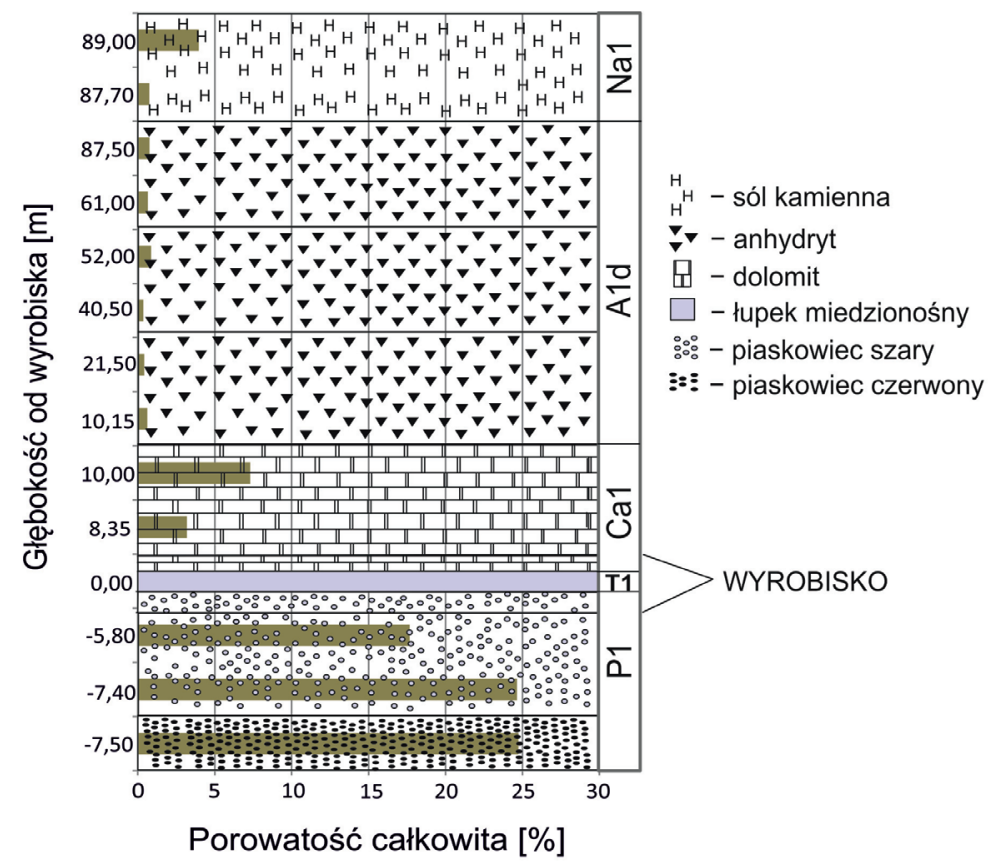

Rys. 5. Zmienność zawartości węglowodorów w gazie desorbowanym i resztkowym w profilu geologicznym otworu

Fig. 5. Variability of the hydrocarbons content in desorbed and residual gas in the geological profile of the borehole

\section{Podsumowanie}

W artykule przedstawiono zmienność ilości i składu gazów pochodzących z degazacji rdzeni skalnych złóż rud miedzi w profilu geologicznym otworu. W celu oceny gazonośności poszczególnych litologii, a tym samym wskazania miejsc potencjalnych pułapek gazowych przebadano skład molekularny oraz ilości wydzielonych gazów desorbowanych i resztkowych w obrębie wybranego otworu pionowego. Dodatkowo wszystkie próbki rdzeniowe poddano badaniom porozymetrycznym oraz przepuszczalności w celu oceny podstawowych parametrów petrofizycznych.

Na podstawie uzyskanych wyników badań można stwierdzić, że ilość wydzielonego gazu resztkowego w całym obrębie profilu otworu doskonale koreluje z właściwościami petrofizycznymi, a dokładniej z wartościami porowatości całkowitej. Próbki pochodzące z serii piaskowcowej (zarówno czerwonego, jak i szarego piaskowca) charakteryzują się najwyższą porowatością całkowitą, sięgającą niemal $25 \%$, i to właśnie w tych porach zostały skumulowane i zamknięte największe ilości gazu resztkowego. Nieco mniejsze ilości gazu wydzieliły się z kolei podczas degazacji próbki dolomitu wapnistego pobranej z głębokości 10,00 m, o stosunkowo wysokiej porowatości całkowitej rzędu 7,3\%, a jeszcze mniejsze z głębokości $8,35 \mathrm{~m}$. Natomiast ilości gazu resztkowego dla soli kamiennej (Na1) oraz dla próbek anhydrytowych (A1d) utrzymywały się na zdecydowanie niższym poziomie.

Z kolei wyniki badań petrofizycznych na próbkach anhydrytowych mogą sugerować, że w analizowanym obszarze nie powinny występować warunki do złożowej koncentracji gazu ze względu na słabe właściwości kolektorskie skał (tj. bardzo niską przepuszczalność oraz małą porowatość). Jednak w przypadku próbki anhydrytowej pobranej z głębokości $52,00 \mathrm{~m}$, o stosunkowo niskiej porowatości całkowitej rzędu $0,9 \%$, wydzieliła się największa ilość gazu desorbowanego (29 270,8 $\mu \mathrm{l} / \mathrm{kg}$ skały) spośród badanych litologii o dużej zawartości azotu nadmiarowego i węglowodorów. W anhydrytach zatem mogą pojawiać się zamknięte „pułapki gazowe”, być może związane z selektywną adsorpcją gazu podczas migracji na duże odległości.

Duże ilości gazu wydzielone z przestrzeni porowej rdzeni w trakcie procesu degazacji związane są z wysoką zawartością azotu nadmiarowego. Największe jego ilości wydzieliły się z serii piaskowców oraz z próbki dolomitu pobranej z głębokości 10,00 m, a więc z rdzeni o dużej porowatości całkowitej.

Spośród badanych próbek, reprezentujących poszczególne serie skalne w profilu geologicznym otworu, to właśnie próbki dolomitów charakteryzowały się zdecydowanie najwyższymi ilościami węglowodorów w gazie resztkowym. Z kolei wyniki badań chromatograficznych na próbkach anhydrytowych 
i soli kamiennej potwierdzają fakt, że w analizowanym obszarze pojawiają się warunki sprzyjające tworzeniu się miejsc kumulacji gazowych z domieszką węglowodorów.

Artykuł powstał na podstawie pracy statutowej pt.: Ocena genezy gazów pochodzacych z degazacji rdzeni skalnych z wykorzystaniem badań izotopowych - praca INiG - PIB na zlecenie MNiSW; nr zlecenia: 0068/SG/2019, nr archiwalny: DK-4100-0058/2019.

\section{Literatura}

Deczkowski Z., Oszczepalski S., Rydzewski A., 1995. Geology of the Żary Pericline and its economic potential. Prace Państwowego Instytutu Geologicznego, 151: 7-22.

Diamond W.P., Schatzel S.J., 1998. Measuring the gas content of coal: a review. International Journal of Coal Geology, 35: 311-331.

Downorowicz S., 2007. Występowanie gazu ziemnego i ropy naftowej. [W:] Piestrzyński A. et al. (red.). Monografia KGHM Polska Miedź S.A. KGHM CUPRUM Sp. z o.o. CBR, Lubin: 142-144.

Janiga M., Kania M., 2014. Degazacja próbek skał - ocena ilościowa i jakościowa gazu resztkowego. Nafta-Gaz, 1: 8-13.

Kania M., Janiga M., 2011. Elementy walidacji metody analitycznej oznaczania w mieszaninie gazowej związków węglowodorowych oraz $\mathrm{N}_{2}, \mathrm{O}_{2}$, CO i $\mathrm{CO}_{2}$ za pomocą dwukanałowego, zaworowego chromatografu gazowego AGILENT 7890A. Nafta-Gaz, 11: 812-824.

Kania M., Janiga M., 2018. Wpływ wykształcenia litofacjalnego na ilość i skład molekularny gazu desorbowanego i resztkowego. Nafta-Gaz, 12: 884-893. DOI: 10.18668/NG.2018.12.02.

Kania M., Janiga M., 2019. Ocena jakościowo-ilościowa gazów pochodzących z degazacji rdzeni skalnych na tle właściwości petrofizycznych skał kompleksu miedzionośnego południowej części monokliny przedsudeckiej. Nafta-Gaz, 6: 314-323. DOI: 10.18668/NG.2019.06.02.

Kłapciński J., Peryt T.M., 2007. Budowa geologiczna monokliny przedsudeckiej. [W:] Piestrzyński A. et al. (red.). Monografia KGHM Polska Miedź S.A. KGHM CUPRUM Sp. z o.o. CBR, Lubin: 69-77.

Kondratowicz G., 1998. Prognoza zagrożenia gazowego złoża rud miedzi zalegającego poniżej poziomu $1200 \mathrm{~m}$. Cuprum, Wrocław: 9: 97-118.

Kotarba M.J., Bilkiewicz E., Manecki M., Pawlik W., Ciesielczyk A., Selerowicz T., 2017. Pochodzenie i zagrożenia siarkowodorem i wysokociśnieniowym gazem ziemnym w złożu kopalń rud miedzi Polkowice-Sieroszowice i Rudna - wstępne badania izotopowe i mineralogiczne. Biuletyn Państwowego Instytutu Geologicznego, 469: 9-34. DOI: 10.5604/01.3001.0010.0068.

Kotarba M.J., Peryt T.M., Kosakowski P., Więcław D., 2006. Organic geochemistry, depositional history and hydrocarbon generation modelling of the Upper Permian Kupferschiefer and Zechstein Limestone strata in south-west Poland. Marine and Petroleum Geology, 23: 371-386.

Poszytek A., Dudek L., Rożek R., 2018. Presence of natural gas in basinal facies of the Zechstein Limestone in a Copper Mine in SW Poland. Journal of Petroleum Geology, 41(1): 67-83.

Poszytek A., Suchan J., 2016. A tight gas reservoir in the basinal facies of the Upper Permian Ca1 in the southwestern Zechstein Basin, Poland. Facies, 62(3): 1-13. DOI: 10.1007/s10347-015-0453-5.

Suchan J., Rożek R., Hryciuk A., 2013. Warunki sedymentacji i zróżnicowanie facjalne wapienia cechsztyńskiego a zagrożenie gazowe i gazogeodynamiczne w O/ZG „Rudna”. KGHM Polska Miedź S.A. V Konferencja Sedymentologiczna POKOS 5', 16-19 maja, Żywiec.

Zawisza L., Krause E., Czekański E., Czopek Z., Dąbrowska B., Dąbrowski J., Gruszka A., Kozimor T., Marcinkowski A., Maruta M., Mularczyk A., Piestrzyński A., Przybyła P., Raś B., Wątor L., Wierzbiński K., Wójtowicz K., 2010. Prognoza potencjalnych obszarów akumulacji gazów, ocena gazonośności skał złożowych i otaczających oraz identyfikacja potencjalnych źródeł emisji węglowodorów wraz z drogami ich migracji w części złóż Sieroszowice, Rudna oraz Głogów Głęboki Przemysłowy. Stowarzyszenie Naukowe im. St. Staszica, Kraków.

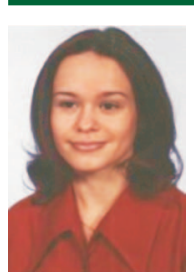

Mgr Małgorzata KANIA

Asystent w Zakładzie Geologii i Geochemii Instytut Nafty i Gazu - Państwowy Instytut Badawczy ul. Lubicz 25 A

31-503 Kraków

E-mail: malgorzata.kania@inig.pl

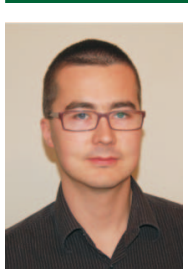

Mgr inż. Marek JANIGA

Asystent w Zakładzie Geologii i Geochemii Instytut Nafty i Gazu - Państwowy Instytut Badawczy ul. Lubicz 25 A

31-503 Kraków

E-mail: marek.janiga@inig.pl

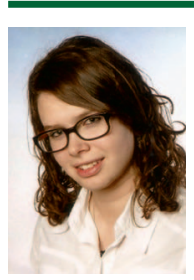

Mgr Agnieszka WCIŚLAK

Zakład Geologii i Geochemii

Instytut Nafty i Gazu - Państwowy Instytut Badawczy ul. Lubicz 25 A

31-503 Kraków

E-mail:agnieszka.wcislak@gmail.com 